struction and standardization of frequency planned in comparative prosperity of 192t-29 and carried out largely in the period of acute depression which followed, resulted in a large increase above the normal capital expenditure of the industry at a time when such expenditure was most needed. The policy had the valuable effect of affording manufacturers in Great Britain extensive and intensive experience in designing and constructing largo high-voltago power plant, thus putting them in a position of equality with their competitors abroad.

Is 192t-25 seventeen different frequencies were employed in the A.c. system of Great Britain. The experts advising the Weir Committeo considered that the standardization desirable for grid purposes, if undertaken in 1924, would cost $10 \frac{1}{2}$ million pounds sterling. By the time the work was actually put in hand, on dates spread over the period 1928-30, the estimated gross cost was $18 \frac{1}{2}$ million pounds. The actual expenditure when the work was complete was $17 \cdot 3$ millions, some part of which is recoverable. Had the decision to standardize been delayed until the present time, the cost would have been well over 30 millions. The savings attributable to the Grid system, already large, would not have been on the same scale had standardization not been undertaken. The national defence requirements have undoubtedly been simplified by the existence of a national standard frequency basis. In conclusion, Mr. Johnstone Wright said that the parts to be played by the Institution in improving and developing the personnel and equip. ment required by the electrical industry and in furthering the cause of international engineering co-operation, aro both onerous and honourable.

\section{Reincarnation of a Dalai Lama}

During the five years which have elapsed since the death of the Dalai Lama of Tibet, reports have appeared of the progress made in the search for his successor. According to Lamaistic belief, when a Dalai Lama dies, his spirit is reincarnated in the body of his successor, born at the moment of his death. The records of early travellers in Tibet bear witness to the elaborato precautions taken to ensure the true succession to the holy office, and the careful, if reverent, regimen to which its youthful occupant is subjected. Lhamo Dhondhup, the new Dalai Lama, now some five years of age, was born in Amdo Ari, near Kumbum, in Silling and at his birth there was a rainbow over the house. Some particulars of the signs by which the authenticity of the reincarnation was attested, as reported from Tibet, are transmitted by the Delhi correspondent of The Times in the issue of October 29. Not only had the existence of the reincarnated Dalai Isama and his whereabouts been indicated in a vision, according to precedent, but also when visited by the search party, disguised as traders, he recognized their holy calling and distinguished between the status of the individuals who composed the party. Ho took hold of the rosary which had belonged to the late Dalai Lama, telling the beads and repenting the Buddhist formula "Om Mane Padme Hum". In a further test, when the Dalai Lama's rosary, small drum and walking stick were offered him, he chose those which had been his own in his previous incarnation in preference to the replicas presented to him at the same time-n test in which another aspirant to the office failerl.

\section{African Studies}

Is "African Survey", Isord Hailey, in discussing the future of African studies, stressed the fact that there was no less need for organized research in the social sciences than in the natural sciences. It was inevitable in a survey of so wide a scopo that any recommendations made would cut across oxisting activities. This was recognized in the credit accorded to existing organizations, in which prominence was given to the work of the International Institute of African Languages and Cultures, not only on account of its specific interests, but also on account of its facilities for collecting information through its international relations. In the recently issued report of the Executive Council of the Institute (Africa, 12, 4,1939 ) it is recalled that discussion of plans for future resenrch had been postponed pending the publication of Lord Hailey's "African Survoy". It is now announced that on the appearance of that report, the authorities of the Institute initiated conversations with Lord Hailey with the view of obviating the dangers of overlap in a common field and com: petition in the sources from which funds are derived. The possibilities of co-operntion are now under discussion, and a scheme for associating the continuation of the Hniley Survey work with the work of the Instituto has already been approved in principle by the Council for elaboration by the Institute's officers.

\section{British Museum (Natural History) : Recent Acquisitions}

Mr. Robert W. OAtes has presented a portrait of J. J. Audubon, the father of American ornithology. This portrait is a copy by Lance Calkin of the so. called hasty portrait which Audubon drow of himself in Liverpool in 1826, and which was reproduced in Buchanan's lifo of Audubon. Unable to find sufficient subscribers in the United States for his projected work on the birds of America, Audubon, at the age of forty-one, came to England for the purpose of finding additional supporters. After visiting a large number of towns in England and Scotland, exhibiting his pictures and meeting a number of well-known people, Audubon collected sufficient subscribers to enable him to commence publication of "The Birds of America". This great work-unique of its kindwas published in Isondon in four volumes (elephant. folio), with life-size drawings of the different birds, between 1827 and 1838. Mr. J. F. Marshall has presented to the Trustees five large oil paintings of birds by $R$. Havell, who engraved many, if not all, the illustrations for Audubon's book.

A BEAUTIFUL specimen of foliated gold in quartz, probably of Australian origin and formerly tho property of the late Walter Claude Johnson, founder of Messrs. Johnson and Phillips, has been presented 